\title{
REMOVAL OF COMMERCIAL ANIONIC DETERGENT IN WATER USING CONTINUOUS PROCESS OF BIOLOGICAL REACTOR WITH ADDING OF PAC
}

\author{
By : \\ Nusa Idaman Said \\ Center for Environmental Technology \\ Agency for The Assessment and Application of Technology
}

\begin{abstract}
Synthetic detergents, mostly anionic detergents have been widely used in Indonesia over past two decades, similar to its use in other developing countries, and residuals from such use have entered the country's riverine and estuarine systems. Detergent problems have become more serious especially in urban areas where the spread of sewerage systems are still low, even in drinking water treatment process. According to this reason, it is important to develop low-cost technology to solve this problem such as developing biological treatment for removing detergents.

Effects OF continuous adding of powdeR activated carbon (PAC) on biological removal of anionic detergent in continuous reactor was assessed. Results of these experiments showed that introduction of PAC into biological treatment of anionic detergent (ABS or $L A S)$, has indicated significant effect on removal efficiency. Conducting continuous feeding of PAC into bench scale of continuous process system for removal of detergent has resulted better stability of MBAS removal efficiency, even when MLSS concentration in aeration tank dropped or MBAS concentration in influent water rose rapidly. With continuous addition of PAC, the MBAS removal efficiency was relatively constant even when the water temperature dropped rapidly. In other words, continuous feeding of PAC can improve the stability for shock loads or temperatures changes. At lower temperatures, micro organisms that were used for detergent removal in bench scale of continuous process system, need longer adaptation or acclimation periods compared with higher temperatures.
\end{abstract}

Key Words: Commercial anionic detergent, biodegradation, biological reactor, powdered activated carbon (PAC).

\section{INTRODUCTION}

Detergents or surfactants now still cause serious problems in many developing countries such as Indonesia. Synthetic detergents, mostly anionic detergents have been widely used in Indonesia over past two decades, similar to its use in other developing countries, and residuals from such use have entered the country's riverine and estuarine systems. Detergent problems have become more serious especially in urban areas where the spread of sewerage systems are still low, even in drinking water treatment process.

According to this reason, it is important to develop low-cost technology to solve this problem such as developing biological treatment for removing detergents. The benefit of biological treatment is not only to remove detergents but also the other biodegradable organics including the removal or reduction of trace organics which recalcitrant to biodegradation and may be toxic or carcinogenic (Bitton, 1994). However, one of the disadvantages of biological treatment is unstable and sensitive toward the loading socks or the changes of temperature.

The disadvantage above can be solved by introducing activated carbon into biological treatment, and this process is often called as biological activated carbon (BAC) process. Nakano and Tamura (1992) stated that using biological activated carbon (BAC) into biological water treatment process can remove odor substances (2-MIB, geosmin), ammonia nitrogen, TOC, trihalomethane precursors, pesticides, detergents and can also remove the by product of the ozone treatment such as aldehyds.

The study of surfactant biodegradation has started during the decade entering on 1950 as a consequence of the chemical revolution which occurred in the detergent industry. At that time the replacement of soap in cleaning and laundry formulation by synthetic surfactants became technically and economically feasible as a result of the commercial development of Alkyl benzene Sulfonate (ABS) then in the the next few years ABS became the surfactant in major use, first in the USA, and soon afterward around the world 
wherever advanced chemical technology made it possible.

Until recently, study on biodegradation of anionic surfactants including biological and biochemical aspects has been conducted by investigators around the world. Some of the more important factors or variables pertinent to surfactant biodegradation include the nature of microorganism - acclimation or adaptation, the nature of surfactants or nutrients, toxic or bacteriostatic agent, temperature, oxygen, initial surfactant concentration etc. Depending on these variables, and too often on others unknown or unrecognized, the biodegradation results may vary. This is a characteristic not only of surfactants, but the other organic compounds as well.

A typical experiment of detergent biodegradation using river water on individual LAS homologs in individual solutions is reported by Fisher (1963). Fisher stated that the biodegradation of LAS is increasingly rapid from the $\mathrm{C}_{6}$ through the $\mathrm{C}_{12}$ homologs, but slower from $C_{12}$ to $C_{15}$ and then faster again to $C_{18}$.

Referred to other experiments done by researchers, Fisher (1970) summarized that :

* Structure of the hydrophobic group is very important determinant of biodegradability. The biological degradation is promoted by increased hydrophobe linearity and deterred by hydrophobe branching, particularly by terminal quarternary branching.

* The nature of the hydrophilic group has only a minor influence on the biodegradability.

- Increased distance between the sulfonate group and the far end of the hydrophobic group increases the speed of primary biodegradation of $A B S$ and possibly of other surfactant types.

The other example of anionic detergent or surfactant biodegradation test has been reported by Okpokwasili and Olisa (1991). Okpokwasili and Olisa have assessed the biodegradabilities of anionic surfactants in four commercial detergents namely Teepol, Apolo, Spencer, Triton X-100 and Sodium Dodecyl Sulphate (SDS), and two shampoos, Flex and Rainbow, using the river water die-away method. The ease of primary degradation over a 12 days period is varied and appears to be related to their sulphate concentrations. Okpokwasili and Olisa were also identified that a microbial consortium comprising the following genera such as Vibrio, Flavobacterium, klebsiella, Pseudomonas, Enterobacter, Bacillus, Escherichia, Shigella, Citobacter, Proteus and Anabaena were found to affect the degradation.

Several studies, as summarized by DeWalle (1976) showed that adding PAC activated sludge process resulted in several improvements in both operation and effluent quality such as removal of colour, odor, and adsorbable or biodegradable organics, increased stability against toxic organic shock loads, reduction of oxygen demand, improved flock forming and sludge settling etc.

Said (1996) has assessed the effects of adding PAC on biodegradation of anionic detergent in batch reactor. Results of the study showed that introduction PAC into biological reactors for removal of anionic detergent (ABS and LAS) has indicated significant effect on removal efficiency. The apparent synergism, that is the total effect of adsorption by activated carbon (PAC) and biological decomposition by microorganism acting together is greater when the aeration process is introduced.

The present study was conducted to investigate the biological removal of commercial anionic detergent in bench scale continuous process and seeded by biological sludges, and with continuous feeding of PAC.

\section{MATERIALS AND ANALYTICAL PROCEDURES}

\subsection{MATERIALS}

\section{Biological Sludge}

The sludge was collected by passing water from Lake Biwa, in Shiga Prefecture, Japan, into gravel bed filter. After more than a week the sludge which attached on the gravel surface of filter medium was collected by washing the gravel medium by lake water. This sludge is called as Lake Biwa Sludge.

\section{Source of Commercial Anionic Detergent}

The commercial anionic surfactant used in this experiment is commercial house hold use detergent purchased from the store, contained many ingredients of surfactant and builder substance such as n-alkyl benzene sulfonic acid sodium (LAS), polyoxyethylene alkyl ether (POE), fatty acid sodium, carbonate, alumino silicate, silicate, enzymes and fluorescent agent (total surfactant $32 \%$ ).

\section{Powdered Activated Carbon (PAC)}

The PAC used during experiment is charcoal powdered activated carbon (treated with $\mathrm{HCl}$ ), produced by Nacalai Tesque Co.Ltd. (Code 079-09)

\subsection{ANALYTICAL PROCEDURES}

All experiments were conducted at Water Supply Engineering Laboratory, Department of 
Environmental and Sanitary Engineering, The University of Kyoto, Japan. The general analysis of $\mathrm{pH}$, suspended solids of sludge, and ABS concentrations were performed according to Japan Standard Method for Drinking Water Quality (JOUSUI SHIKENHOU) or Waste Water Quality (GESUI SHIKENHOU).

The anionic surfactant concentrations were measured by Methylene Blue Method as methylene blue active substances (MBAS).

\section{EXPERIMENTAL METHODS}

A bench scale of continuous process system unit consist of five liters of aeration tank (reactor) and two liters of settling tank (clarifier) was operated. Initially, both aeration tank and clarifier were seeded with Lake Biwa sludge. Detergent solution and PAC slurry were fed into the reactor (aeration tank), and be aerated continuously by air pump. The sludge that settled in the clarifier was transferred into aeration tank by a recycle pump. Detergent solution was prepared by diluting commercial anionic detergent and PAC slurry was prepared by diluting PAC with tap water. The system was operated continuously, and after a certain elapsed time, $\mathrm{pH}$ and MBAS concentration in both influent and treated waters, MLSS concentration in reactor and SS in effluent were measured periodically.

\section{RUN 1 :}

Initial Condition :

Both aeration tank and clarifier seeded with mixture of Lake Biwa sludge and PAC (10 mg/l).

Raw Water : Lake water.

Operating Conditions :

HRT in Aeration Tank = 3.97 hours (4hrs.)

HRT in Clarifier $=95 \mathrm{~min}$.

Hydraulic Recycle Ratio $(\mathrm{HRR})=2.3$

PAC Feeding $=10 \mathrm{mg} / \mathrm{l}$ (continuous)

Flow sheet of experiment Run 1 is shown in Figure 1.

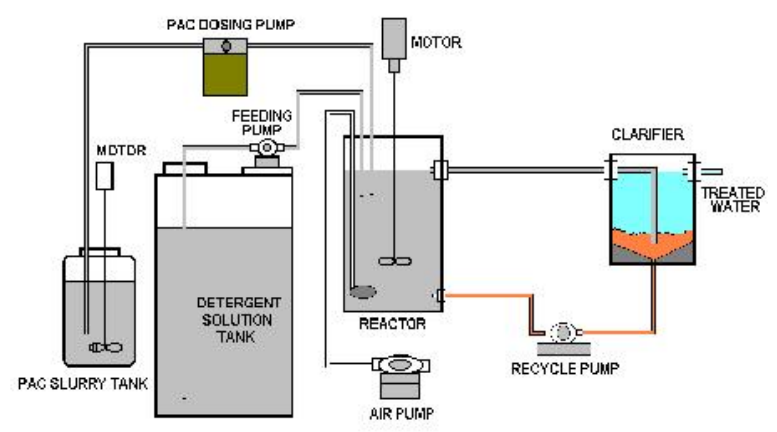

Figure1. Flow sheet experiment Run 1.

\section{RUN 2 :}

Initial Condition :

Aeration tank and clarifier seeded with only Lake

Biwa Sludge.

Raw Water : Lake Biwa water.

Operating Condition :

HRT in aeration tank $=4$ hours

HRT in Clarifier = 95 min

Hydraulic Recycle Ratio = 2.3

PAC Feeding $=10 \mathrm{mg} / \mathrm{l}$ (continuous)

Flow sheet of experiment Run 2 is shown in Figure 2.

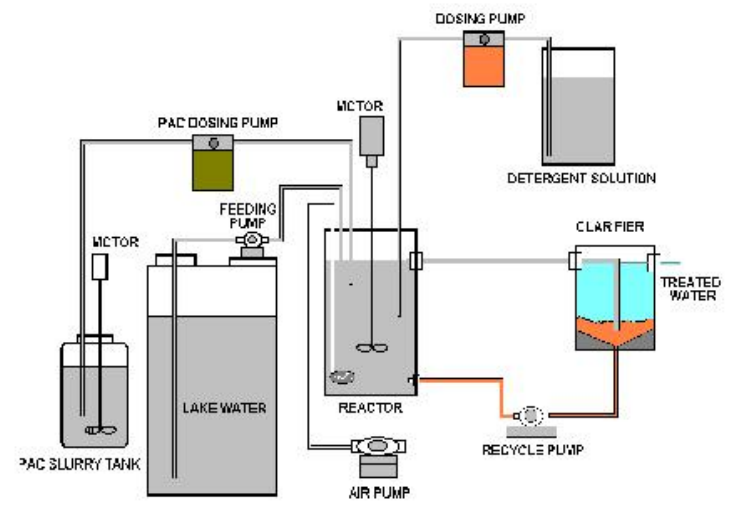

Figure 2. Flow sheet experiment Run 2.

\section{RESULTS AND DISCUSSION}

\section{RUN 1 :}

Experiment Run 1 was conducted at room temperature condition, and water temperature was about $18-22{ }^{\circ} \mathrm{C}$. The results of experiment Run 1 are shown in figures 3 to Figure 6 . Figure 3 shows the changes of $\mathrm{pH}$ and MBAS concentration both in influent and treated waters. MBAS concentrations in influent were in the range of $1.78-2.1 \mathrm{mg} / \mathrm{l}$ and MBAS concentrations in treated water varied in the range of $0.08-0,205 \mathrm{mg} / \mathrm{l}$. $\mathrm{pH}$ value in the influent water varied from 6.6 to 6.65 , whereas the $\mathrm{pH}$ values in the treated water varied from 6.9 to 7.12. Similar to the previous experiments, $\mathrm{pH}$ of treated water increased.

Figure 4 represents the MBAS concentrations in influent and effluent or treated waters, and MBAS removal efficiency. Removal efficiency varied between 85.94 and $95.45 \%$. At 4 hour elapsed time MBAS removal was about $91 \%$, and at 25 hour elapsed time, MBAS removal efficiency decreased to about $85 \%$, then increased gradually, and reached up to $90 \%$ after 48 hour elapsed time. According to this result, it was presumed that at initial stage of 
process the removal of detergent predominantly was caused as result of adsorption by PAC and sludge, after that the detergent removal was caused as result of adsorption by PAC and biological decomposition by microorganisms simultaneously. The average removal efficiency was about $92 \%$.

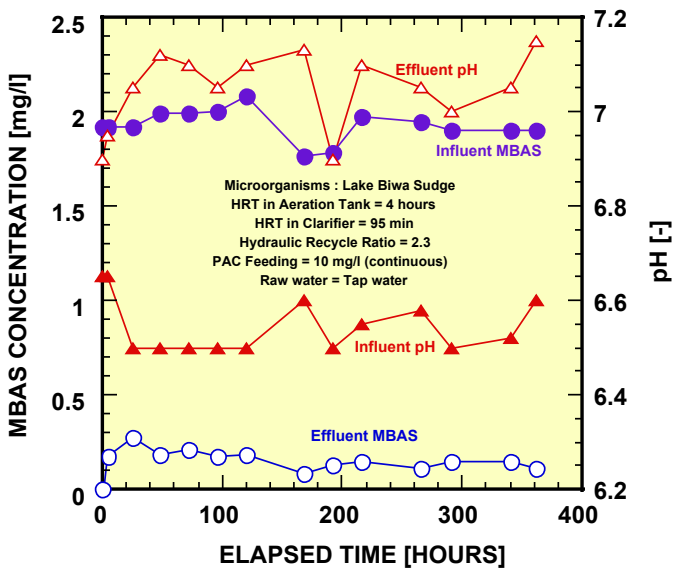

Figure 3. Biodegradation of Commercial Anionic Detergent in Bench Scale of Continuous Process System Seeded with Lake Biwa Sludge with Continuous Feeding of PAC. First, aeration tank and clarifier were seeded with Lake Biwa sludge and PAC $10 \mathrm{mg} / \mathrm{l}$.

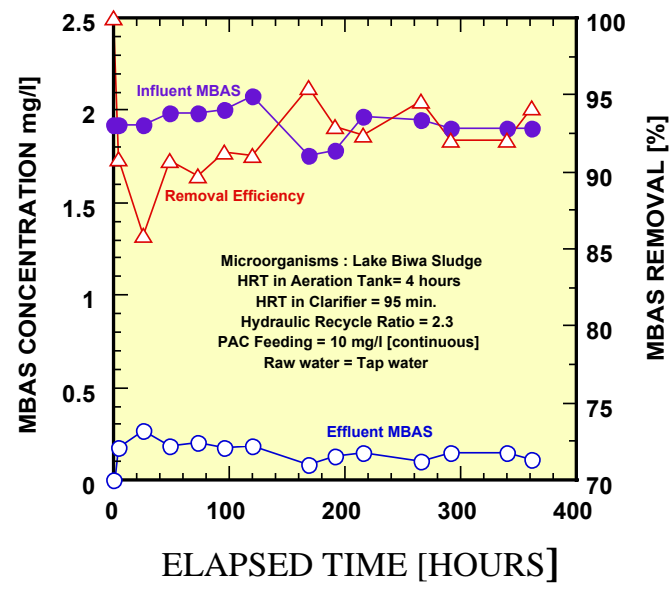

Figure 4. Removal Efficiency of Commercial Anionic Detergent in Bench Scale of Continuous Process System Seeded with Lake Biwa Sludge with Continuous Feeding of PAC.

Figure 5 shows the relationship between MLSS concentration in aeration tank and SS concentration in effluent water. The initial MLSS concentration in aeration tank was about 1600 $\mathrm{mg} / \mathrm{l}$, and after 120 hour elapsed time, it decreased to about $530 \mathrm{mg} / \mathrm{l}$. SS concentration in effluent water at 4 hour elapsed time was $94 \mathrm{mg} / \mathrm{l}$ and after 120 hour elapsed time, it decreased to around $20 \mathrm{mg} / \mathrm{l}$. This result is generally similar to the previous experiment.

Figure 6 shows the relationship between MBAS removal efficiency and MLSS concentration in reactor or aeration tank. In the previous experiment, PAC was fed into aeration tank and clarifier only at the beginning of operation together with sludge. However, in this experiment (Run 1), firstly aeration tank and clarifier were seeded with mixture of Lake Biwa sludge and $10 \mathrm{mg} / \mathrm{l}$ PAC, and then PAC slurry was fed into aeration tank continuously. In experiment without continuous feeding of PAC, when the MLSS concentration decreased, the MBAS removal also decreased. However, with continuous feeding of PAC, the MBAS removal was relatively constant, although the MLSS concentration in aeration tank decreased.

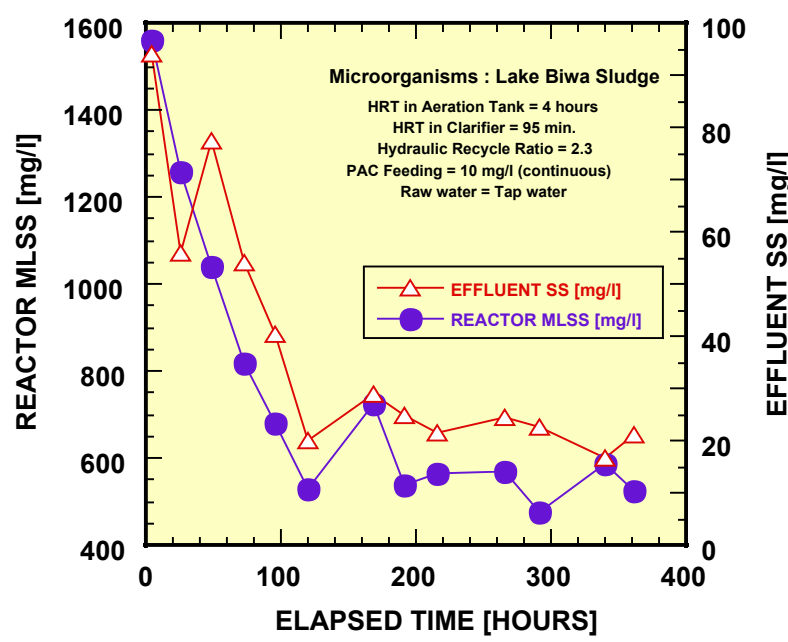

Figure 5. Relationship between MLSS Concentration in Aeration Tank and SS concentration in Treated water.

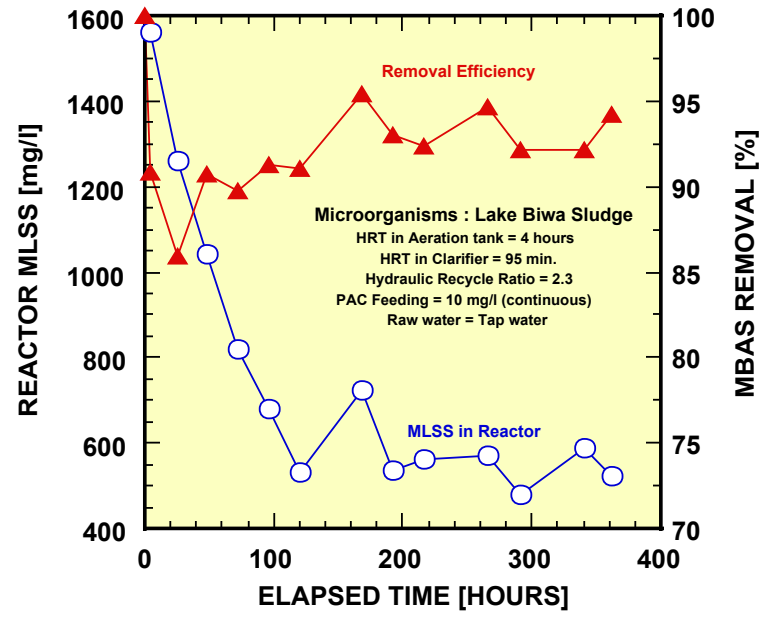

Figure 6. Relationship between MBAS Removal Efficiency and MLSS Concentration in Aeration Tank. 
Figure 7 shows the MBAS removal efficiency of commercial anionic detergent in bench scale of continuous process system seeded with Lake Biwa sludge with continuous feeding of PAC compared with the MBAS removal efficiency of when fed only by PAC (without sludge).

\section{RUN 2 :}

Experiment Run 2 was done at room temperature condition and water temperature fluctuated in the range of $12.1-17.4{ }^{\circ} \mathrm{C}$. Comparing to Run 1, the temperatures were dropped rapidly. In Run 2, natural water (Lake Biwa Water) was used as source of raw water, whereas both detergent and PAC were diluted with tap water. PAC feeding was stopped after reaching 583 hour (about 3 weeks) elapsed time. The results of experiment of Run 2 are shown in figures 8 to Figure 12.

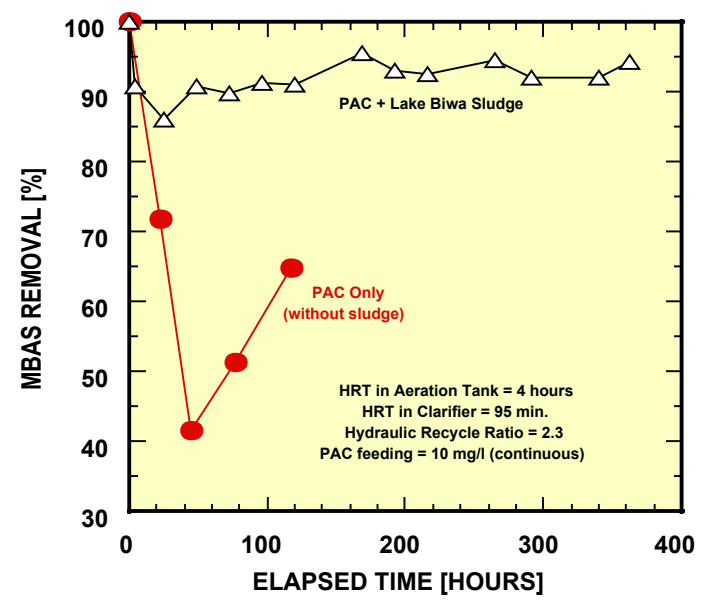

Figure 7. MBAS Removal Efficiency in Bench Scale of Continuous Process System with Continuous Feeding of PAC Seeded with and without Lake Biwa Sludge.

Figure 8 shows the changes of $\mathrm{pH}$ and MBAS concentration both in influent and effluent waters. In the initial step of process MBAS concentration in effluent water increased sharply to about $0.86 \mathrm{mg} / \mathrm{l}$ at 24 hour elapsed time, then decreased gradually, and after reaching elapsed time more than 120 hours, MBAS concentration in effluent was still decrease even the MBAS concentration in influent increased. The MBAS concentration gradually increased again after PAC feeding was stopped.

Figure 9 shows the MBAS in both influent and effluent waters, and MBAS removal efficiency. In the initial step of process MBAS removal efficiency dropped rapidly until reaching to around $54 \%$ at 26 hour elapsed time. The removal efficiency then gradually increased, and reached to around $90 \%$ at elapsed time more than 200 hours. In Run 2, MBAS removal efficiency at initial step of process is lower compared with Run 1. This phenomenon was probably caused as result of the difference in acclimation or adaptation time that needed by microorganisms in both experiments. The adaptation time of microorganisms in Run 2 seems longer than in Run 1, because water temperature in Run 2 was lower than water temperature in experiment Run 1 . The decreasing removal efficiency at initial periods of process in Run 2 may also be caused as result of difference in the seeding method of sludge. In Run 1 aeration tank and clarifier were seeded with mixture of Lake Biwa sludge and PAC (10 $\mathrm{mg} / \mathrm{l})$ before starting operation, while in Run 2 only Lake Biwa sludge was seeded, So that adsorption of detergent by PAC at initial step of the process in Run 1 is higher than in Run 2. The MBAS removal efficiency gradually decreased again after PAC feeding was stopped (after 583 hour operation).

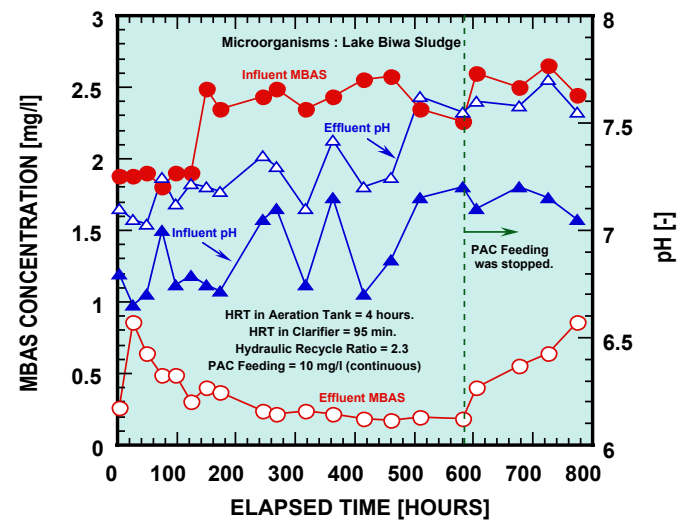

Figure 8 . Biodegradation of Commercial Anionic Detergent in Bench Scale of Continuous Process System Seeded with Lake Biwa Sludge with Continuous Feeding of PAC. Aeration tank and clarifier were seeded with Lake Biwa sludge. Raw water : Lake Biwa water, temperature 12 -18 ${ }^{\circ} \mathrm{C}$.

Figure 10 shows the SS concentration in effluent water and MLSS concentration in aeration tank. Generally, the changes of MLSS and SS concentration in Run 2 exhibited similar pattern to Run 1. However, in Run 2, after reaching elapsed time more than 414 hours MLSS concentrations in aeration tank began to increase. This might be caused as a result of decreasing SS concentration in the effluent, so that the SS concentration in influent water was 
higher than SS concentration in effluent water and accumulated in aeration tank.

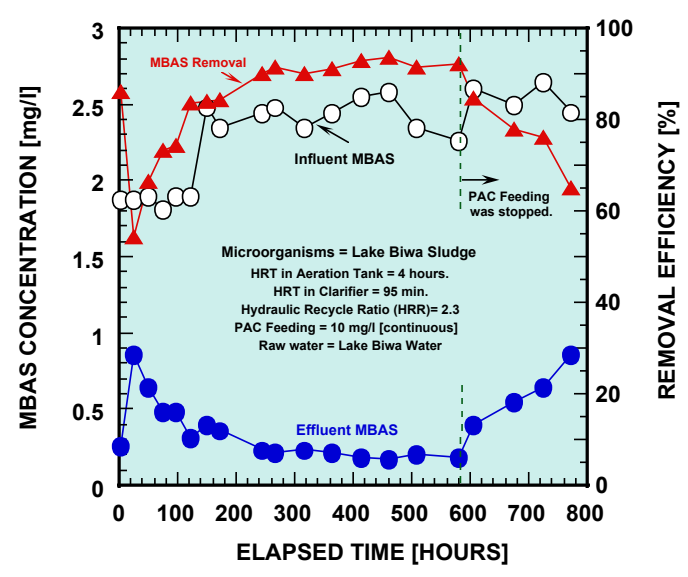

Figure 9. Removal Efficiency of Commercial Anionic Detergent in Bench Scale of Continuous Process System Seeded with Lake Biwa Sludge with Continuous Feeding of PAC. Aeration tank and clarifier were seeded with Lake Biwa sludge. Raw water : Lake Biwa water, temperature 12 -18 ${ }^{\circ} \mathrm{C}$.

Figure 11 shows the changes of MLSS concentration in aeration tank and the changes of MBAS removal efficiency. Similar to the results of Run 1, with continuous feeding of PAC into activated sludge system, MBAS removal efficiency was almost constant even when MLSS concentration in aeration tank decreased or MBAS concentration in influent increased.

Figure 12 shows the MBAS removal efficiency, dissolved oxygen in aeration tank, and water temperature in Run 2. According to this figure, it can be seen clearly that with continuous feeding of PAC, MBAS removal efficiency was relatively constant even when the water temperature dropped rapidly.

Figure 13 shows the relationship between MLSS concentration in aeration tank and MBAS removal efficiency in Run 1 and Run 2. According to this figure it can be seen that MLSS concentration in experiment using Lake Biwa water (Run 2) is relatively higher than MLSS concentration when tap water was used as raw water (Run 1). This was probably caused by the fact that Lake Biwa water contained higher concentration of suspended solids or microorganisms and nutrients than tap water, so that the bacterial growth in run 2 was higher than in Run 1.

The removal rate of MBAS both in Run 1 and Run 2 have also been calculated using the following equation.
MBAS REMOVAL RATE $=\frac{[\mathrm{C} \text { in }-\mathrm{C} \text { out }]}{\text { MLSS x Q }}$
[gr-MBAS/gr-MLSS.day $]$

where : $\mathrm{C}_{\text {in }}$ is MBAS concentration in influent water (mg/l); Cout is MBAS concentration in effluent water $(\mathrm{mg} / \mathrm{l})$; $\mathrm{Q}$ is flow rate of influent water (I/day ); MLSS is SS concentration in aeration tank $(\mathrm{mg} / \mathrm{l})$. The results of the calculation are shown in Figure 14. The removal rate of MBAS varied from 0.0053 to $0.02195 \mathrm{gr}$ MBAS/gr-MLSS.day.

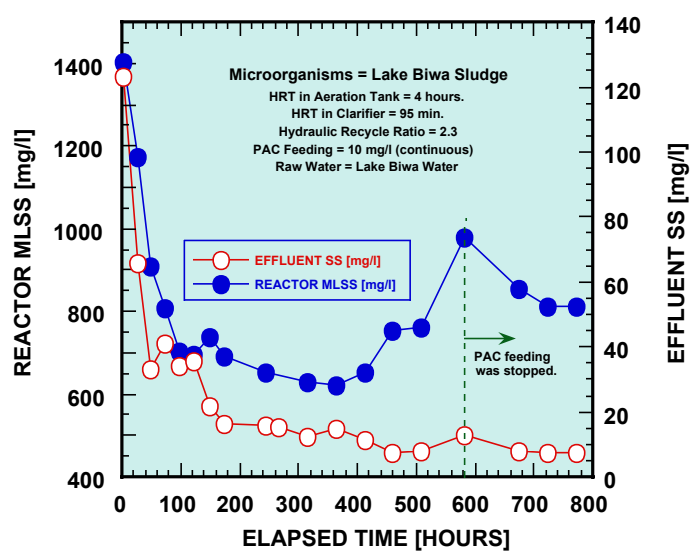

Figure 10. Relationship Between MLSS Concentration in Aeration Tank and SS Concentration in Treated Water.

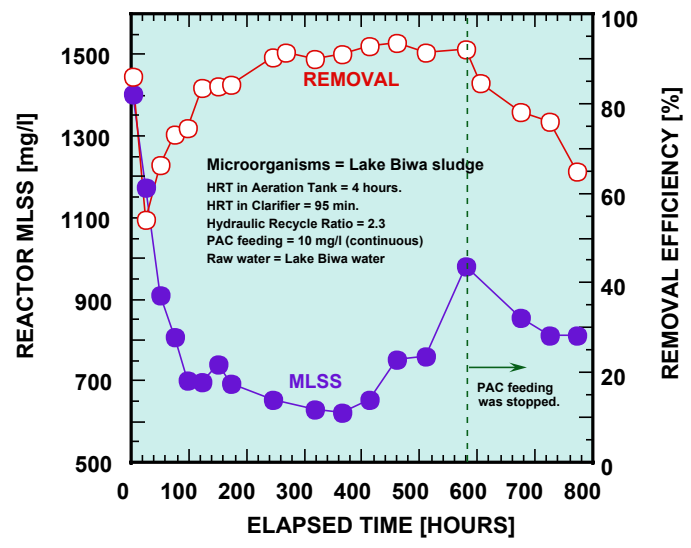

Figure 11. Relationship between MBAS Removal Efficiency and MLSS Concentration in Aeration Tank. 


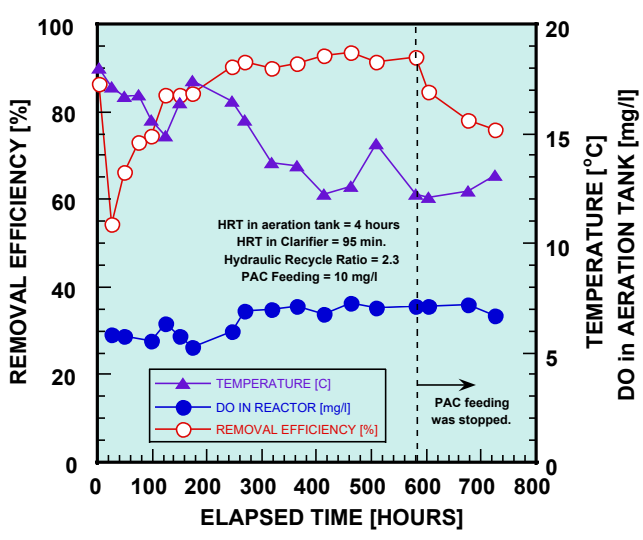

Figure 12. MBAS Removal Efficiency, Dissolved Oxygen in Reactor and Temperature of water.

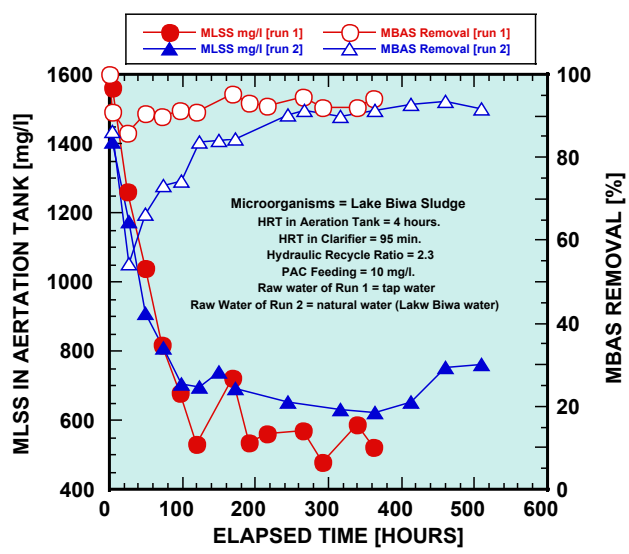

Figure 13. MBAS Removal Efficiency and MLSS Concentration in Bench Scale of Continuous Process System Seeded With Lake Biwa Sludge with Continuous Feeding of PAC.

Run 1 : Aeration Tank and Clarifier were seeded with Lake Biwa sludge + PAC $10 \mathrm{mg} / \mathrm{l}$.

Run 2 : Aeration Tank and Clarifier was seeded with only Lake Biwa sludge.

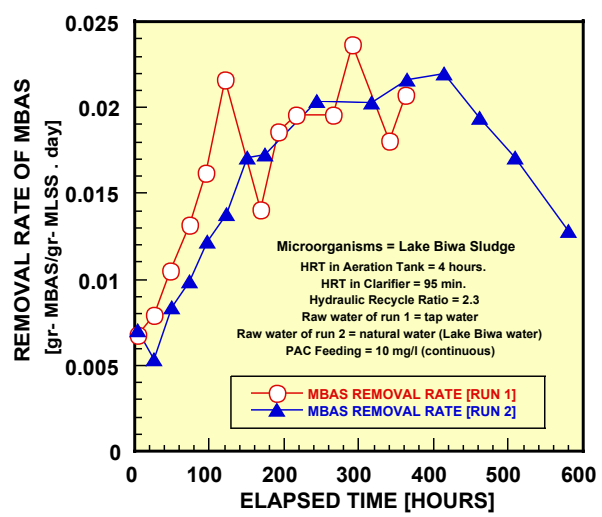

Figure 14. Removal Rate of Commercial Anionic Detergent in Bench Scale of Continuous Process System Seeded With Lake Biwa Sludge with Continuous Feeding of PAC.
Run 1 : Aeration Tank and Clarifier were seeded with Lake Biwa sludge + PAC $10 \mathrm{mg} / \mathrm{l}$.

Run 2 : Aeration Tank and Clarifier was seeded with only Lake Biwa sludge.

\section{CONCLUSION}

On the basis of the results obtained throughout this study, the following conclusions are drawn :

- Conducting continuous feeding of PAC into bench scale of continuous process system for removal of detergent has resulted the more stable condition of MBAS removal efficiency, even when MLSS concentration in aeration tank dropped or MBAS concentration in influent water rose rapidly.

- With continuous addition of PAC, the MBAS removal efficiency was relatively constant even when the water temperature dropped rapidly. In other words, continuous feeding of PAC can improve the stability for shock loads or temperatures changes.

- At lower temperatures, microorganisms which were used for detergent removal in bench scale of continuous process system, need longer adaptation or acclimation periods compared with higher temperatures.

\section{REFFERENCES}

1. APHA (1985) Standard Methods for the Examination of Water and Waste water, 16th edition. American Public Health Association, New York.

2. Bitton G. (1994) Wastewater Microbiology. Wiley-Liss, New York.

3. Gesui Shikenhou (Standard Methods for Waste water Analysis). Nihon Gesuidou Kyoukai, 1984.

4. Ide T. (1990) Mizushori Kougaku (Water Treatment Engineering), Second edition. Gihoudou, 1990. Japan.

5. Jousui Shikenhou (Standard Methods for Drinking Water Analysis), 1985 edition. Nihon Suidou Kyoukai, 1985. (Japanese Edition)

6. Karigome T. (1987) Kaimen Kasseizai Bunsekihou (The methods of Surfactant Analysis), New Edition. SAIWAI SHOBOU, 1987. (Japanese edition).

7. Nakano S. and Tamura T.( 1992) Seibutsu Kasseitanhou ni yoru Mi-zushori Gijutsu. Kogyou Yousui (journal of Industrial Water). No.441, 1992. p.41-51. 
8. Nakano S. and Tamura T.( 1992) Seibutsu Kasseitanhou ni yoru Mizushori Gijutsu. Kogyou Yousui (journal of Industrial Water). No.441, 1992. p.41-51.

9. Nihon Bunseki Kagakukai Hokkaido Shibu (The Japan Society for Analytical Chemistry , Hokkaido. (1981) Mizu no Bunseki, 3rd Edition. Kagaku Dojin, Japan. (Japanese Edition)

10. Okpokwasili and Olisa (1991) River-Water Biodegradation of surfactant in Liquid Detergents and Shampoos. Water Research, Vol.25, No.11, pp.1425 to 1429 , 1991.

11. Said, Nusa Idaman, Study on Adsorption of Anionic Detergent by Powdered Activated Carbon (PAC) and by Biological Sludge. PII Journal, Vol.03, No. 02, 1995
12. Sawyer C.N. and Mc Carty P.L.(1967) Chemistry for Sanitary Engineers. Mc Graw Hill- Kogakusha, Tokyo.

13. Sublette, Snider and Sylvister (1982) A Review of the Mechanism of Powdered Activated Carbon Enhancement of Activated Sludge Treatment. Water Research. Vol.16, pp. 1075 to $1082,1982$.

14. Swisher R.D. (1963) Biodegradation of $A B S$ in Relation to Chemical structure. Journal Water Purification Control Federation (WPCF), Vol.35, No.7, July 1963.

15. Swisher R.D. (1970) Surfactant Biodegradation. Dekker, New York. 